\title{
VERSITA
}

\section{Financial and Banking Regulation and Supervision within the EU}

\section{Constanze Lehleiter}

\author{
Dealis Fund Operations \\ Governance, Risk and Compliance, \\ Herriotstr. 1, \\ Frankfurt am Main D-60528, Germany \\ E-mail: constanze.lehleiter@dealis.de
}

\begin{abstract}
The European Union (EU) has faced not only the international financial crisis, but also the European banking and the sovereign debt crisis. A lack of efficient regulations and supervision were a serious cause of recent developments. As a reaction, the EU finally implemented a framework covering both micro- and macro-prudential policies. Measures such as the new capital requirements, the deposit guarantee schemes, the green paper on shadow banking and, most importantly, the new approach for a macro-prudential supervision are headed towards crisis prevention. However, the challenge is to define regulations enhancing financial stability, which, at the same time, do not prevent institutions from generating reasonable financial risks and do not reduce growth. In that regard, the presented measures still have deficits which have to be faced. Furthermore, coordination between various authorities and the European Commission remains another challenge.
\end{abstract}

Keywords: $C R D / C R R$, crisis prevention in the EU, financial market regulation, macro-prudential supervision, SSM

\section{Introduction}

Europe was hit strongly by recent economic developments and the focus of the EU has changed from a functioning internal market before the outbreak to stable and well-regulated financial markets in the aftermath of the crisis. The EU has had to react to the European crisis, which is composed of three different developments that even triggered each other. 
First of all, the international crisis, interpreted by Strauss-Kahn as the 'great recession' (Wearden, 2009) seriously hit European countries. Recent developments with origins in the United States' mortgage loan sector have affected international financial markets and, partly, have spread further to public finances and the real economy was also seriously affected. Although the origins and causes of these developments are numerous (for a thorough summary of the causes see Larosière et al., 2009) it can be concluded that the crisis is the outcome of a markets' and regulations' failure and of an ineffective risk management (Mildner, 2012). It spread over to the European market because many European banks had invested in the US mortgage sector.

Secondly, at the same time a European banking crisis was developing. Also, loans have increased dynamically within the EU while interbank activities have enlarged. The overheating of real estate markets in some Member States, also triggered by the reduction of interest rates, led to its collapse and to immense credit losses. Serious consequences on the banking sector followed, especially within Ireland and Spain (Issing, 2012). Alongside inefficient capital and liquidity management, risks of financial innovation, of interconnectedness between banks and governments and of shadow banks also the regulation and supervisory systems failed within Europe. Systemic relevance has been ignored.

Finally, the EU consisting of eurozone and non-eurozone countries had its structural deficits already before the outbreak of the international financial and European banking crisis. The so-called sovereign debt crisis of some eurozone members had its origins not only in the international financial crisis but also in fundamental shortcomings of the eurozone. In the case of Greece and Italy, for example, developments of debts were considerable already before 2007 (Issing, 2012). By lending money to governments, the fragility of banks was already affected by the sovereign debt crisis. They lost a part of their credit receivables.

In order to react immediately to this 'systematic crisis' (Sachverständigenrat, 2012 b, p. 5) especially high-debt countries such as Greece, Portugal, Spain and Ireland were supported by fiscal crisis-management measures and by both monetary policy and non-standard policy measures of the European Central Bank (ECB). In any case, existing regulation and supervision mechanisms could neither mitigate the effects of the crisis nor prevent its causes.

The main objective of this paper is to give an overview about how the EU responded to recent developments and its causes in order to improve crisis prevention and whether it did it in an effective way. Crisis prevention means reduction of the probability and severity of crises and systemic risks within the 
EU and globally. It may be achieved by enhancing financial stability. However, measures aimed to improve financial stability may have negative side effects on real economic processes such as competition and growth. As banks are an extremely important funding source for enterprises within Europe and the structural reform may have consequences for credit intermediation, the impact of measures not only for financial markets but also for the whole economy will be mentioned, too.

The paper is focussed on the banking sector as banks have a pivotal role for the $\mathrm{EU}$ and thus are especially vulnerable in times of crisis.

\section{Key issues of financial and banking integration within the EU}

To be able to assess the crisis-prevention actions taken by the EU it is important first to consider the fundamental characteristics of the European financial market and especially its banking sector. It is most important to see this market embedded in the continuous process of integration.

\subsection{The banking sector within the EU financial market}

The EU financial market consists of 28 national markets with differences regarding its economical origins and to some extent regarding its currencies. Within the banking sector, however, clusters can be built regarding shares of assets, loans, deposits and also employees. The first cluster consists of banks residing in the EU-15 countries building the core of the intra-EU banking market. The second cluster consists of banks residing in countries which became member of the EU with the eastward expansion in 2004. Although its power in the form of EU-wide assets, loans and deposits is much smaller compared to the first cluster, the figures increased instead of declining, contrary to many of the EU-15 banks (European Banking Federation, 2012).

Central and Eastern European (CEE) countries were not affected by the crisis as much as the Western European countries. There are considerable differences regarding their bank performance: In 2011, the return on equity of Estonia, Lithuania, Poland, the Czech Republic and Slovakia dominated the top of the ranking lists. Furthermore, almost all banks of the CEE countries exceed the ratio of bank capital to assets compared to EU-15 countries (European Banking Federation, 2012). 


\subsection{Structural shortcomings before the crisis}

Structural problems existing in the EU financial market in general and in its banking sector in particular contributed a lot to the poor developments. The most important ones will be presented below. First of all, the capital adequacy of many systemic relevant banks was insufficient. In Germany, for example, mainly banks with low capital adequacy were affected by the developments (Sachverständigenrat, 2012a). Secondly, banks and governments are interconnected with each other either through direct ownership participation of governments in banks or owing to the fact that banks buy government bonds. This relationship can have negative consequences in times of crisis, as it was the case in many crisis countries such as Ireland and Spain. Furthermore, until the outbreak of the crisis, partly due to the objective of integrating financial markets, European banks were highly interconnected. Their financing was increasingly taken up through the interbank market and a short-term exchange of liquidity was possible. Becoming at the same time more vulnerable to systemic risks, an effective restructuring in the crisis was difficult, also as international interdependence augmented (Sachverständigenrat, 2012a). Fourthly, a further structural problem evolving already before the outbreak of the financial crisis was the change of revenue and financing structure of banks. Related to the balance sheet total, interest income has decreased, while income from more volatile transactions leading to a higher market risk increased. Concerning the financing through the bond markets, the proportion of secured financing increased, especially among banks in the crisis countries (European Central Bank, 2012a).

Finally, also the European banking sector suffered from a clear lack of adequate macro-prudential supervision for financial markets. There was no effective early warning mechanism that could have translated assessment of risk into action (Larosière et al., 2009).

\subsection{Financial integration: Advantages and shortcomings}

Originally, financial integration within the EU has been seen as a catalyst for economic growth. If market integration reached its optimal form, more opportunities for risk diversification, better allocation of capital and higher economic growth may be the result (Commission of the European Communities, 2007).

In its 2007 European Financial Integration Report, the Commission reports about an almost complete integration in the unsecured interbank deposit market and 
government bond market and a rising degree of integration of equity markets and corporate bonds. Furthermore, before the outbreak of the crisis, EU financial markets became increasingly open for international activities. Innovation in the form of new products, distribution channels and market practices increased. However, already in this report the Commission admits that integration may also serve as a channel for cross-border contagion, transmitting risks across the financial system (Commission of the European Communities, 2007).

After the outbreak of the crisis the trend of financial market integration changed. Markets are becoming increasingly fragmented, which is reflected in the interbank payment system TARGET2 (European Central Bank, 2012b). On the interbank market, the share of cross-border transaction has decreased, and domestic assets are used progressively as collaterals for refinancing operations with the ECB. Furthermore, risk premiums for cross-border bank transactions have risen, while corporate interest rates partly clearly differ between the eurozone countries (Sachverständigenrat, 2012a).

While the EC still considers the completion of the single market in financial services as a crucial measure in order to stimulate economic recovery in Europe, the focus has changed. Today, integration of financial markets also means to establish a crisis-prevention regulatory framework and a banking union (BU) with a Single Supervisory Mechanism (SSM).

\section{The most important crisis-prevention policies taken or considered by the EU}

As shown by recent developments, micro-prudential regulation may become inefficient in sufficiently managing risks and discovering them timely. Therefore, today, acute crisis management is accompanied by creating a new legislative framework of financial market rules and by changing the architecture of the European financial markets. The macro-prudential approach is taken into account (for detailed information about this approach see Hanson, Kashyap \& Stein, 2011).

Until now, the Commission has not only proposed all the main legislations linked to G-20 commitments, but has also adopted or proposed additional provisions aimed to stabilise the single market in financial services and to efficiently implement it. Additionally, institutional changes of supervisory mechanisms have been undertaken and are still in the development process. 


\subsection{Responding to insufficient capital adequacy}

During the last three decades, the Basel Committee on Banking Supervision (BCBS) has developed essential provisions concerning the banking sector. Its recommendations are the relevant international standard for banking regulation, especially on capital adequacy, the core principles for effective banking supervision and a concordat on cross-border banking supervision (BIS, 2013). On the EU level these recommendations have been transposed into the Capital Requirement Directive (CRD).

a) EU legislation in force: The CRD actually consists of two directives: Directive 2006/48/EC, which is related to the taking up and pursuit of the business of credit institutions and Directive 2006/49/EC focussing on the capital adequacy of investment firms and credit institutions (European Parliament and the Council, 2006a,b).

In order to ensure the consistent application of Basel II (which is based on three pillars: the minimum capital requirements, the supervisory review process and market discipline), these directives determine the prudential framework for investment firms and credit institutions. According to Basel II, different approaches to capital adequacy, which allow institutions to use risk-measuring methods best suited to their risk profile, were established. Supervisory authorities assess the amount of risk capital that institutions must have at their disposal depending on the type of risk - either credit risk, market risk or operational risk. The rules concerning credit risks are set out in Directive 2006/48/EC whereas Directive 2006/49/EC is concerned with market and operational risks faced by investment firms and credit institutions.

As a first reaction to the crisis, the Commission strengthened the regulatory framework in those areas which were relevant to the causes of the crisis. In May 2009, the Council and the EP officially adopted Directive 2009/111/EC (European Parliament and the Council, 2009b), which is part of the so-called CRD II package. In order to safeguard the financial safety of banks and investment firms Basel II was thereby more specified and a basis for implementation at national level was created (Schulte-Mattler \& Dürselen, 2009). A further amendment followed with Directive 2010/76 (European Parliament and the Council, 2010a), which was adopted in November 2010 (CRD III package).

b) Upcoming legislation: $C R D I V$ and CRR: Although the amendments of the CRD were one step towards enhanced crisis-prevention and financial stability, Basel II has been criticised for its extreme complexity, its difficulty to be adapted to irregular situations and its likelihood to lose control over the system as a 
whole (Ohler, 2009). Thus, systemic risks were still not sufficiently covered by this measure.

Table 1. Rough overview of the capital requirement measure (CRD/CRR IV)

\begin{tabular}{|c|c|c|}
\hline \multirow[b]{2}{*}{ Goals } & \multicolumn{2}{|l|}{ Regulation Dimension / Measures } \\
\hline & $\begin{array}{l}\text { Stability of a single bank } \\
\text { (micro-prudential) }\end{array}$ & $\begin{array}{l}\text { Banking system resilience } \\
\text { (macro-prudential) }\end{array}$ \\
\hline $\begin{array}{l}\text { Strenghtening } \\
\text { capital base } \\
\text { of the banking } \\
\text { system }\end{array}$ & $\begin{array}{l}\text { Quality and quantity of capital base: } \\
\text { Stricter eligibility rules, core equity, } \\
\text { contingent capital, new narrowly } \\
\text { defined Common Tier } 1 \text { Ratio } \\
\text { (CET1), new/increased deductions; } \\
\text { unrealised gains and losses }\end{array}$ & $\begin{array}{l}\text { Capital buffer to limit excessive } \\
\text { credit growth: } \\
\text { Introduction of capital conservation } \\
\text { and countercyclical capital buffers; } \\
\text { higher capital requirements for } \\
\text { systemic derivatives }\end{array}$ \\
\hline $\begin{array}{l}\text { Restricting } \\
\text { leverage }\end{array}$ & $\begin{array}{l}\text { Maximum leverage ratio (gross, non } \\
\text { risk-based, on and off balance sheet } \\
\text { items at full conversion) }\end{array}$ & \\
\hline $\begin{array}{l}\text { Increasing } \\
\text { liquidity }\end{array}$ & $\begin{array}{l}\text { Short-term stressed ratio (Liquidity } \\
\text { Coverage Ratio) }\end{array}$ & $\begin{array}{l}\text { Derivatives: Longer margin periods } \\
\text { on positions (to reflect potential } \\
\text { liquidity) }\end{array}$ \\
\hline $\begin{array}{l}\text { Strengthening } \\
\text { funding }\end{array}$ & $\begin{array}{l}\text { Long-term structural ratio (Net } \\
\text { Stable Funding Ratio) }\end{array}$ & \\
\hline $\begin{array}{l}\text { Enhancing risk } \\
\text { coverage }\end{array}$ & $\begin{array}{l}\text { Capital intensives for using central } \\
\text { counterparties instead over-the- } \\
\text { counter transactions; } \\
\text { higher capital for inter financial } \\
\text { institution exposures; } \\
\text { higher capital for counterparty } \\
\text { credit risk (derivatives, repos and } \\
\text { securities) }\end{array}$ & $\begin{array}{l}\text { Derivatives (higher risk weights } \\
\text { if not cleared bu a central } \\
\text { counterparty); } \\
\text { interconnectedness (higher risk } \\
\text { weights to exposures to financial } \\
\text { institutions due to high correlation of } \\
\text { rating drop); }\end{array}$ \\
\hline $\begin{array}{l}\text { Enhancing risk } \\
\text { assessment and } \\
\text { measurement }\end{array}$ & $\begin{array}{l}\text { Correcting risk-measurements } \\
\text { methods (assessing market risk } \\
\text { under stress scenarios) }\end{array}$ & $\begin{array}{l}\text { Reducing pro-cyclicality: Use } \\
\text { probability-of-default estimates } \\
\text { from downturn periods, forward- } \\
\text { looking expected-loss approach to } \\
\text { provisioning. }\end{array}$ \\
\hline
\end{tabular}

Source: Composed by the author based on European Parliament, 2011

As a consequence, Basel III was published in December 2010 by BCBS. In order to transpose it into EU law, in July 2011 the EC adopted a legislative package with the main objective to make the financial system more resilient to future crises. The proposal of the renewed capital requirement provisions comprises two legal acts, a directive and a regulation, which shall replace the current Directives 2006/48 and 2006/49. Not all transposed measures correspond exactly with the Basel III rules. Some are proposed in addition. 
Main parts of the Basel III framework are implemented by the regulation, which is directly applicable (European Parliament and the Council, 2011a). It provides for detailed prudential requirements for credit institutions and investment firms and regulates relevant subjects like own funds, liquidity, leverage ratio and counterparty risk. This so-called 'Single Rule Book' is an important renewal, as national discretions shall be mainly abolished.

Complementarily, the directive governs, amongst others, the principles of prudential supervision (European Parliament and the Council, 2011b). The subjects of the Directive are fundamentally based on Basel III, nevertheless, it includes further details and extensions of requirements into the proposal. New issues are requirements regarding corporate governance, sanctions, capital buffers and supervisory processes. Being adopted by the EP in April 2013 both the CRR and CRD IV are expected to come into force by January 2014. In accordance with certain transitional regimes, the requirements of the CRR shall become fully operational by January 2019. Based on Basel III the new EU provisions will explicitly face micro- and macro-prudential objectives.

\subsection{Responding to further challenges}

The Commission created numerous further provisions concerning not only the banking sector but also other sectors of financial markets. Two of them will be addressed in this context.

a) Missing liquidity and lack of confidence:Also derived from a G-20 commitment, the Deposit Guarantee Scheme Directive (DGSD, European Parliament and the Council, 2009a) shall strengthen consumer confidence and investor protection. It protects the bank deposits of depositors in the event of bank insolvency and may contribute to financial stability by preventing depositors from making panic withdrawals from their banks (European Commission, 2013b). Aiming to further harmonise the DGS, the Commission proposed in July 2010 an amending provision. In its proposal, it restricts the maximum repayable amount to 100,000 euros for each depositor and DGS will be obliged to mutually grant loans to other schemes that cannot fulfil its obligation (European Parliament and the Council, 2010b). The proposal is of special importance because it is foreseen to be a main element of the envisaged BU.

b) Shadow bank systems: Shadow banks have played an important role triggering the crisis, but within the EU they had not been in the focus of regulation and supervision until now. Risks are especially seen in its systemic-relevant nature, its cross-jurisdictional reach and its interconnectedness to the regular banking 
system. This is especially risky as they can be used to avoid regulation or supervision (European Commission, 2012b).

In March 2012, the Commission presented its Green Paper Shadow Banking, which essentially analyses four issues: the definition of shadow banks and their activities, the advantages and drawbacks of shadow banks, the already existing regulation on those and how future regulation should be. As defined by the Commission, shadow banks are, for example, investment funds, finance companies or insurance and reinsurance undertakings, which provide alternative credits for investors without being subject to regulations of the banking sector, such as to the CRD. It is estimated that shadow banks manage approximately one quarter of the whole volume of the financial sector (European Commission, 2012b).

\subsection{Responding to inefficient supervisory mechanisms}

The original European supervisory framework consisted of three financial committees for micro-financial supervision but did not include a body responsible for supervision of systemic risks. As a consequence, for the first time a framework for both micro- and macro-prudential supervision was defined under special consideration of the 'Larosière report' (Europa Press Release, 2009).

a) Legislation in force: The European System of Financial Supervisors (ESFS): Between 2009 and 2011 numerous reforms of the supervision system took place. As a first step, a European Systemic Risk Board (ESRB) was established and three new European authorities for the supervision of financial activities were set up: the European Banking Authority (EBA), the European Securities and Markets Authorities (ESMA) and the European Insurance and Occupational Pensions Authorities (EIOPA). These authorities shall work in tandem within the newly established ESFS, which also consists of a network of national financial supervisors. The three European Supervisory Authorities (ESAs) shall closely cooperate with the ESRB (European Parliament and the Council, 2010c). The new system came into force in January 2011.

The role of the ESRB is to monitor and assess macro-prudential aspects whereas cooperating national authorities and the three newly created authorities carry out micro-prudential supervision.

b) A new proposal: The Single Supervisory Mechanism (SSM): Although systemic supervision today is exercised by the ESRB, there are still lacks concerning its competences to directly intervene. Furthermore, the surveillance of macro-prudential regulations is still given to national authorities. 
The Commission suggested a set of legislative proposals on the establishment of a SSM for banks led by the ECB. It has to be seen as a first step towards a BU, which shall also consist of a single rulebook, common deposit protection and a single bank resolution mechanism. The proposal includes a regulation conferring strong powers on the ECB related to supervisory tasks and another allying the existing regulation on the EBA to the proposed set-up and a communication outlining the overall vision of the EC for the envisaged BU (Europa Press Release, 2012). The European Parliament, the European Council and the Commission recently agreed on that proposal; formally it is not yet adopted.

The new mechanism will apply to all eurozone Member States while it is open to the participation of the other EU countries. It confers elementary supervisory tasks and powers to the ECB. The ECB will be responsible for the supervision of all 6,000 banks of the eurozone; however, it directly supervises the highly 'significant' banks (which have either assets of more than 30 billion euros, constituting at least 20 per cent of their home country's GDP or have requested or received direct public financial assistance from the European Financial Stability Facility or European Stability Mechanism). At the same time, national supervisors will still directly supervise the other banks in their member states. The ECB monitors this process and is able to decide to directly supervise also these banks (European Parliament and the Council, 2012, Art. 4, 5). The Commission considers the new role of the ECB therefore as the key to delink sovereign and banking risks (European Commission, 2013a).

\section{Evaluation of the success or failure of the most important measures}

At this point it should be mentioned that external influences or shocks will never be fully prevented. As financial risks represent the core of the businesses of financial institutions they will have to deal again with it (Draghi, 2008). Thus, the central question is in how far the EU responses will enhance crisis prevention by either achieving a stable financial banking system or by discovering an upcoming risk timely. It is further important to analyse potential side effects and impacts on other economic processes. 


\subsection{Capital requirements}

\subsubsection{Impacts on financial stability}

By analysing the impact of CRD and CRR on the capital structure, on the leverage and on the liquidity ratio of financial institutions, an assessment of its contribution to financial stability is possible.

a) Capital structure: There are especially three measures within the new provisions that may have a positive effect on the capital structure.

Firstly, the stricter definition of the capital base of an institution will contribute to financial stability. As well-capitalised banks have a better performance over the business cycle (European Parliament, 2011), it seems reasonable to build up the quality capital. However, what has to be mentioned critically is that the EU did not change the risk-weighting of government bonds of EU countries within the definition of the Common Equity Tier 1 capital (CET1 is capital, which has to be of highest quality, see European Parliament and the Council, 2011a, Art. 109). Especially the sovereign debt crisis has shown that there is also a default risk for government bonds. Basel III, on the contrary, requires risk weights up to 150 per cent.

Secondly, the introduction of the capital conservation and the counter-cyclical buffers that is foreseen under the new provisions seems to be reasonable. In times of economic upswings capital buffers are often reduced to the level of MCRs and in times of downturns the level increases. According to a study of ECB, such buffers will dampen if not preserve the pro-cyclical pattern (Maurin \& Toivanen, 2012c).

Finally, the CRR requires separate capital for the counterparty credit risk (CCR) concerning derivatives and repos and securities. This will have positive impacts on the financial stability of both single institutions and the whole system. The risk measurement will be improved in order to be able to better address the CCR. Risk weights on exposures to financial institutions will rise as these are more highly interconnected and therefore increase the systemic risk (European Banking Authority, 2013). Additionally, there is an incentive given to use central counterparties (CCPs) as the risk weighting with those will be treated as privileged; thus, more capital has to be fed up by not using CCPs (European Parliament and the Council, 2011a, Art. 373, 374, 384).

b) Leverage Ratio: The leverage ratio indicates a minimum level of capital as a proportion of total assets. It will limit the incentive of banks to underestimate risk 
within internal valuation models, which further may lead to wrong risk-weightsdetermination of capital (Blum, 2008). Nevertheless, the strategy to introduce the ratio only in 2018 is seen controversially. This measure is considered to be more transparent and convenient to monitor than the other capital requirements. Therefore not only the delay in introduction but also the envisaged minimum of 3 per cent is being criticised (e.g., by the Sachverständigenrat, 2012a).

c) Liquidity: The liquidity of a financial system is important in order to be able to absorb financial instabilities resulting from the high interconnectedness of the banks within the EU. Higher liquidity ratios will reduce the risk of contagion and destabilisation of financial market resulting from a negative shock (European Parliament, 2011). Thus, as liquidity requirements shall increase the buffer of banks in the case of a liquidity-shortage, the introduction of the two envisaged liquidity ratios (Liquidity Coverage and Net Stable Funding Ratio) seems reasonable.

\subsubsection{Impact on banks' profitability}

Lending and funding are the core activities of banks. Banks have to adjust the implications of the new measures of its overall balance sheet and decisions on lending rates will affect the overall quantity of loan volume. Increasing capital requirements mean that additional core capital must be built up by institutions. Provisions of credit may become restricted. Thus, capital and liquidity requirements may have negative impacts on the profitability of financial institutions.

The EP found that the negative effects of increased capital requirements on interest rates are modest. By the gradual implementation of the new measures, capital may be built up smoothly and by the adaption of risk perception of equity and debts to the new risk profile the potential short run effect is further reduced (European Parliament, 2011).

However, according to the European Parliament (2011, p. 66) only these modest negative effects raise incentives to "mitigate credit-creation activities to the shadow banking sector and tilt the level playing field of banks within the EU". A major drawback of capital requirements may be the incentives for achieving regulatory arbitrage through the shadow banking system. Therefore the timely and adequate implementation of the proposed rules on shadow banking is very important. 


\subsubsection{Social costs: Impact on business cycles and economic growth}

Although modestly, the new measures have an impact on the ability to lending activities, which will spill over to the capital market as households and firms depend on these. This may lead to negative effects on the business cycle and economic growth in the short term. Especially in the EU there are still downward shocks to growth and growth needs to be enhanced especially in crisis countries. In order to prevent serious consequences for small and medium enterprises, credits up to 1.5 million euros will not have a higher risk-weight and therefore will not lead to higher interest rates (European Parliament and the Council, 2011a, Art. 148).

However, the impact may be negative especially for the CEE economies, as a harmed investment climate may reduce the significant growth potential of this area (European Banking Federation, 2012). For example, the liquidity ratio requirement, being a part of the CRR, applies uniformly to all EU countries and to banks of all sizes irrespective of their business model. But the measure may be not suitable for all countries, as some do not have the markets to extend long-term funding for banks due to the absence of a bond market in the domestic currency (IMF, 2011).

Furthermore, the definition of the CET1 is wider than that of the Basel III proposal. In a way that the other states introduce the narrow defined rule, EU financial institutions may be seen as less 'healthy' compared to other global competitors (Schuster, 2013).

Another scenario is that the requirements will not be fully transposed by other states outside the EU. If, for example, the US will not adopt them, there will be negative impacts for the EU regarding its quality of location. As only European credits will become more expensive, investigations will be done preferably in other states. Furthermore, given the openness of financial markets, the aim of stabilising the European market may fail.

\subsection{Impacts by further regulations}

\subsubsection{Deposit Guarantee Schemes}

Generally, it is important to have a mechanism enhancing consumer confidence concerning its deposits in banks. Nonetheless, the new proposal of the DGSD is seen very critically. Two issues are important: First of all, it does not seem to be reasonable to restrict the maximum repayable amount to 100,000 euros. This rule would reduce the deposit guarantee level in some Member States and 
reducing the level may lead even to consumer mistrust, instead of confidence. Therefore, in the worst-case scenario, it may destabilise financial markets (CEP, 2010). It could further lead to the distortion of competition between the different countries. Secondly, the obligation to mutually borrow loans between DGSs will not lead to more financial stability. Contagion and domino effects may appear, at least as long there is no holistic supervision for all banks into force (CEP, 2010). Furthermore, smaller banks would have to establish additional deposit guarantees in order to fulfil the obligation to mutually borrow loans (Drost \& Menzel, 2010).

\subsubsection{The Green Paper Shadow Banking}

It was inevitable to finally focus on shadow banks, which have systemicrelevant character and still represent a risk for financial stability. Thus, enhanced transparency, regulation and supervision for those banks are essential and it is reasonable to restrict lending by shadow banks to regular banks.

However, the Commission defines the scope for the term 'shadow banking' too broadly. Not all of the enumerated institutions are out of the scope of regulations and supervision, for example, investment funds and money market funds are already regulated (by the so-called OGAW and AIFM Directive). Therefore, the paper should focus on institutions that are really working in the shadow. Furthermore, the envisaged plan that the according authorities shall develop a concept for shadow banking and define the level of supervision is disputed. It would be better to give this task to legislative level (CEP, 2012a).

\subsection{The envisaged supervisory framework}

\subsubsection{Impacts on financial stability}

Given the close interconnection of many European banks and the fact that national authorities do not cooperate most efficiently, a well-functioning centralised supervision is indispensable. According to the SSM, the ECB will be responsible for the 130 largest banks, amongst them highly systemic-relevant ones. In addition, by a centralised, supranational supervision national interests become less favoured and same cases will be treated with same supervisory measures, at least in theory (CEP, 2012b).

However, some issues of the proposal are risky and need to be guarded against. First of all, although the newly created Supervisory Board will exercise operational supervisory tasks, the Governing Council consisting only of eurozone countries will have to take final decisions of both monetary policy 
and supervisory issues (see European Parliament and the Council, 2012, Art. 19). Thus, potential conflicts are predicted concerning interest-rate decisions and the objective of price stability risks may become incredible. Estimations of higher inflation may follow and the financial market may become instable (CEP, 2012b). Furthermore, as fiscal consequences on supervisory decisions are even able to influence credit ratings of governments in times of crisis, governments will try to influence decisions of the ECB and, thus, its supervisory independence is less likely (IMF, 2013).

\subsubsection{Further consequences}

The new supervisory framework affects eurozone and non-eurozone countries differently. Only eurozone countries and those who want to join the SSM are covered by the new mechanism. However, the UK is a highly important financial market, too. As it will certainly not join the SSM, a holistic supervision of all systemic risks within the EU may still not be given.

Besides, even in case a non-eurozone country wants to participate in the SSM, it cannot vote on the Council (see also Statute of the ESCB and of the ECB, Art. 10). Thus, envisaged special arrangements have to consider seriously the maintaining of a level playing field for such countries (IMF, 2013).

\section{Conclusion and further steps to be taken}

The new regulations coupled with the new supervisory system are key steps towards financial stability and thus, crisis prevention. However, in order not to lead to a reduced economic growth they have to fit into the roadmap for stability, growth and jobs and have to be coordinated with the Commission DG Competition. Further, in order to be fully effective, some issues are not yet sufficiently covered. Especially the following three chapters should be faced.

a) Improvements of capital requirements and further measures: Some measures of the new capital requirements are not in line with the Basel III proposal. That may be reasonable in certain cases; however, for the following issues an alignment is crucial. Firstly, the EU did not clearly answer to the risk of interconnectedness between banks and governments. It is highly important to provide an adequate capital base for governments bonds as states may fail. Thus, in line with Basel III, not only private but also government bonds should be risk-weighted (see European Parliament and the Council, 2011a, Art. 115). Secondly, the European definition of CET1 is neither in line with Basel III. As mentioned already, European banks 
may be weakened within the international competition and in the long run they are most likely forced to strengthen the definition of CET1, anyhow (European Commission, 2012a). Finally, the leverage ratio should be implemented in line with the Basel III proposal. It contributes to financial stability and is more transparent and convenient to monitor than the MCRs.

Measures for shadow banking should be implemented as soon as possible since negative side effects of the capital requirements may be an enhanced activity within this sector. However, in its present wording, the paper for shadow banking risks overregulating financial markets. In order to prevent this, the term shadow banks should be defined more narrowly.

b) Facing challenges by establishing the SSM and the BU: The establishment of the SSM and the envisaged BU are important steps towards financial stability and further integration. Nevertheless, legal, institutional and operational consequences have to be considered. Despite the fact that the ECB is not designed for a supervisory function, the legal basis for establishing the SSM is Article 127(6)TFEU. Resulting challenges such as interest conflicts, dependences on nationalities, strictly operational division of supervisory and monetary policy without preventing synergies between the two functions, have to be faced by establishing a comprehensive framework for transparency and accountability (IMF, 2013).

The most challenging fact can be seen in the three different groups to be surveyed in the future: eurozone countries, non-eurozone countries joining the SSM, and countries not joining the SSM. In order to assure financial stability for the whole single market a lot of coordinating activities between ECB, the EBA, national authorities and among the latter are necessary. Data management and information sharing between the different entities is highly important. Thus, respective roles of national authorities and ECB has to be specified and rules defining the division of labour created (IMF, 2013).

Regarding the establishment of an entire BU there are further challenges. The harmonised DGS is mostly criticised and its feasibility without an EU treaty change is discussed. A treaty change would not be undertaken within a shortterm period. Therefore, in order not to halt the integrating developments of the BU, a more-step approach is proposed by some politicians and experts (Euractiv, 13 May 2013). The first steps may include all integration activities possible without a treaty amendment whereas further steps would be made to integrate also changes, which need time to meet the conditions in order to be efficiently implemented. 
c) Further steps towards a stronger EU financial oversight framework: Establishing a holistic supervisory framework for the whole EU financial sector, including also the insurance and capital market sector will be a necessary step in order to face all the challenges on the financial markets and reduce the risk of shadow banks. The IMF (2013) underlines the importance of harmonising capital requirements' resolutions, DGS and also insurance supervision frameworks at EU level.

Establishing such a risk-landscape mainly raises challenges of coordination between the various supranational agencies and the national authorities. The measures also have to be coordinated with other rules aimed to enhance growth; thus, DG Competition has to be involved, as well. A further mechanism or committee may become relevant. It should integrate the work of the ESAs, the ESRB, the SSM, the forthcoming resolution authority and DG Competition (IMF, 2013). Furthermore, administrative activities will even increase and it is still not sure whether such a holistic supervision may work effectively. Without doubt, its implementation is fundamental in order to improve financial stability.

Constanze Lehleiter has recently completed her master's degree in European Union Studies at the Centre International de Formation Européenne (cooperating with the Hungarian Academy of Sciences, the Humboldt University of Berlin and the University of Cologne). Within the studies she focussed on financial and banking regulation. She obtained a master's degree in Business Administration from the Humboldt University of Berlin in 2003. She has more than ten years of work experience in the financial sector, amongst others with Allianz Global Investors. The main emphasis of her work is on the identification of business-related risks and the analysis and integration of new processes and international regulatory requirements.

\section{References}

BIS (2013), About the Basel Committee, Bank For International Settlements, Basel Committee on Banking Supervision. Retrieved from http://www.bis.org/bcbs/ about.htm8 [accessed 10 May 2013]

Blum, J. M. (2008), "Why 'Basel II' may need a leverage ratio restriction", Journal of Banking and Finance, vol. 32, no. 8, pp. 1699-1707.

CEP (2010), 'Deposit Guarantee Schemes,' cep-analysis, 11 October 2010, Freiburg: Centrum für Europäische Politik. Retrieved from www.cep.eu/fileadmin/user upload/Kurzanalysen/Einlagensicherung_Neufassung/PB_Deposit_Guarantee_ Schemes.pdf [accessed 20 May 2013] 
- (2012a), 'EU-Grünbuch Schattenbankwesen (Green Paper Shadow Banking),' cep-analysis, no. 43/2012, 25 June 2012, Freiburg: Centrum für Europäische Politik. Retrieved from http://www.cep.eu/fileadmin/user_upload/Kurzanalysen/ Schattenbanken/KA_Schattenbanken.pdf [accessed 20 May 2013]

- (2012b), 'EU-Verordnung EZB-Bankenaufsicht (ECB Banking Supervision),' cep-analysis, no. 47/2012, 19 November 2012, Freiburg: Centrum für Europäische Politik. Retrieved from http:/www.cep.eu/uploads/tx_cpspolitmonitor/CEPAnalyse_COM_2012-511_EZB-Bankenaufsicht.pdf [accessed 20 May 2013]

Commission of the European Communities (2007), European Financial Integration Report 2007, Commission Staff Working Document, Brussels: Commission of the European Communities.

Draghi, M. (2008), How to restore financial stability? Lecture held on 16 September 2008, Retrieved from http://www.bis.org/review/r080922b.pdf [accessed 27 May 2013]

Drost, F. \& Menzel, S. (2010), 'Streit über den Schutz der Sparer,' Handelsblatt Online, 30 September 2010. Retrieved from http://www.handelsblatt.com/politik/ deutschland/eu-einlagensicherung-streit-ueber-den-schutz-der-sparer/3551314. html [accessed 27 May 2013]

Euractiv (2013), 'Schäuble: Echte Bankenunion nur mit Vertragsänderung,' Euractiv Online, 12 May 2013. Retrieved from http://www.euractiv.de/finanzen-undwachstum/artikel/schaeuble-echte-bankenunion-nur-mit-vertragsaenderung-007517 [accessed 27 May 2013]

Europa Press Release (2009), 'Financial services: Commission proposes stronger financial supervision in Europe,' Europa Press Release, 27 May 2009. Retrieved from http://europa.eu/rapid/press-release_IP-09-836_en.htm?locale=en [accessed 20 March 2013]

- (2012), 'Commission proposes new ECB powers for banking supervision as part of a banking union,' Europa Press Release, 19 September 2012. Retrieved from http://europa.eu/rapid/press-release_IP-12-953_en.htm?locale=en [accessed 21 March 2013]

European Banking Authority (2013), Basel III monitoring exercise: Results based on data as of 30 June 2012. Retrieved from http://www.eba.europa.eu/cebs/media/ Publications/Other\%20Publications/QIS/EBA-BS-2012-037-FINAL--ResultsBasel-III-Monitoring-.pdf [accessed 20 May 2013]

European Banking Federation (2012), Facts \& Figures 2012. Retrieved from http:// www.ebf-fbe.eu/uploads/FF2012.pdf [accessed 20 April 2013]

European Central Bank (2012a), Financial Stability Review, June 2012, Frankfurt: European Central Bank.

(2012b), Indicators of Market Segmentation, Media request following the ECB press conference on 2 August 2012. 
European Commission (2012a), Budget and economic policy advice for EU countries 2012-2013. Retrieved from http://ec.europa.eu/news/economy/120531_en.htm [accessed 20 May 2013]

_ (2012b), Green Paper Shadow Banking, 19 March 2012, COM(2012)102 final, Brussels: European Commission.

- (2013a), A new financial system for Europe. Financial reform at the service of growth, Brussels: Internal Market and Services.

— (2013b), Deposit Guarantee Schemes. Retrieved from http://ec.europa.eu/ internal_market/bank/guarantee [accessed 19 March 2013]

European Parliament (2011), CRD IV: Impact Assessment of the Different Measures within the Capital Requirements Directive IV, Brussels: Directorate-General for Internal Policies.

European Parliament and the Council (2006a), Directive 2006/48/EC of the EP and of the Council of 14 June 2006 relating to the taking up and pursuit of the business of credit institutions, The Official Journal of the European Union, L 177 of 30 June 2006, pp. 1-196.

_ (2006b), Directive 2006/49/EC of the EP and of the Council of 14 June 2006 on the capital adequacy of investment firms and credit insitutions, The Official Journal of the European Union, L 177 of 30 June 2006, pp. 201-255.

(2009a), Directive 2009/14/EC of the EP and of the Council of 11 March 2009 amending Directive $94 / 19 / \mathrm{EC}$ on deposit-guarantee schemes as regards the coverage level and the payout delay, The Official Journal of the European Union, L 68 of 13 March 2009, pp. 3-7.

(2009b), Directive 2009/111/EC of the EP and of the Council of 16 September 2009 amending Directives 2006/48/EC, 2006/49/EC and 2007/64/EC as regards banks affiliated to central institutions, certain own funds items, large exposures, supervisory arrangements, and crisis management, Text with EEA relevance, The Official Journal of the European Union, L 302 of 17 September 2009, pp. 97-119.

(2010a), Directive 2010/76/EU of the EP and of the Council of 24 November 2010 amending Directive 2006/48/EC and 2006/49/EC as regards capital requirements for the trading book and for re-securitisations, and the supervisory review of remuneration policies, The Official Journal of the European Union, L 329 of 14 December 2010, pp. 3-35.

(2010b), Proposal for a Directive of the EP and of the Council on Deposit Guarantee Schemes, COM(2010)DGS of 12 July 2010.

- (2010c), Regulation (EU) No 1095/2010 of the EP and of the Council of 24 November 2010 establishing a European Supervisory Authority (European Securities and Markets Authority), amending Decision No 716/2009/EC and repealing Commission Decision 2009/77/EC, The Official Journal of the European 
Union, L 331 of 15 December 2010, pp. 84-119.

(2011a), Proposal for a Regulation of the EP and of the Council on prudential requirements for credit institutions and investment firms, COM(2011)452 of 20 June 2011 .

(2011b), Proposal for a Directive of the EP and of the Council on the access to the activity of credit insitutions and the prudential supervision of credit institutions and investment firms and amending Directive 2002/87/EC of the EP and of the Council on the supplementary supervision of credit institutions, insurance undertakings and investment firms in a financial conglomerate, COM(2011)453 of 20 June 2011. (2012), Proposal for a Council Regulation conferring specific tasks on the ECB concerning policies relating to the prudential supervision of credit institutions, COM(2012)511 of 12 September 2012.

Hanson, S. G.; Kashyap, A. K. \& Stein, J. C. (2011), 'A macroprudential approach to financial regulation', Journal of Economic Perspectives, vol. 25, no. 1, pp. 3-28.

IMF (2011), 'How to address the systemic part of liquidity risk,' Global Financial Stability Report, April 2011, Washington D. C.: IMF, pp. 75-110.

- (2013), European Union: Financial System Stability Assessment, IMF Country Report no. 13/75, March 2013. Retrieved from https://www.imf.org/external/pubs/ $\mathrm{ft} / \mathrm{scr} / 2013 / \mathrm{cr} 1375$.pdf [accessed 27 May 2013]

Issing, O. (2012), 'Die Krise der Europäischen Währungsunion,' Das Wissenschaftsmagazin. Forschung Frankfurt, no. 2/2012, pp. 24-27.

Larosière, J. de et al. (2009), The High-Level Group on Financial Supervision in the EU, [Report] Brussels, 25 February 2009.

Maurin, L. \& Toivanen, M. (2012), Risk, capital buffer and bank lending, Working Paper Series, no. 1499, November 2012.

Mildner, S.-A. (2012), 'Ursachen der Finanzkrise: Ein Blick in die USA,' Bundeszentrale für politische Bildung, pp. 1-4. Retrieved from http://www.bpb.de/politik/ wirtschaft/finanzmaerkte/135463/ursachen-der-finanzkrise? $p=$ all [accessed 27 May 2013]

Ohler, C. (2009), International Regulation and Supervision of Financial Markets after the Crisis, Working Paper on Global Financial Markets. Retrieved from http:// www.db-thueringen.de/servlets/DerivateServlet/Derivate-20941/04.pdf [accessed 27 May 2013]

Sachverständigenrat (2012a), Stabile Architektur für Europa (Stable Architecture for Europe), Jahresgutachten 2012/13, Paderborn: Sachverständigenrat zu Begutachtung der gesamtwirtschaftlichen Entwicklung.

(2012b), Nach dem EU-Gipfel: Zeit für langfristige Lösungen nutzen, 5 July 2012, Paderborn: Sachverständigenrat zu Begutachtung der gesamtwirtschaftlichen Entwicklung. Retrieved from http://www.sachverstaendigenrat-wirtschaft.de/ fileadmin/dateiablage/download/publikationen/sg2012.pdf [accessed 27 May 2013] 
Schulte-Mattler, H. \& Dürselen, K. (2009), 'CRD - Änderungsrichtlinie. Weiterentwicklung der europäischen Bankenaufsicht,' Die Bank. Zeitschrift für Bankpolitik und Praxis, vol. 9, September 2009. Retrieved from http://www.diebank.de/index.php?id=107\&tx_ttnews[tt_news]=12931\&cHash=1c67d28d9232d b0c4ec7710812f82e6f [accessed 27 May 2013]

Schuster, T. (2013), 'Der EU-Vorschlag für Eigenkapitalanforderungen (II),' EurActiv, 25 April 2013. Retrieved from http://www.euractiv.de/druck-version/artikel/dereu-vorschlag-fr-eigenkapitalanforderungen-ii-007462 [accessed 27 April 2013]

Wearden, G. (2009), "IMF: World economy to shrink for first time in 60 years in 'Great Recession',' The Guardian Online, 10 March 2009. Retrieved from http:// www.guardian.co.uk/business/2009/mar/10/imf-great-recession [accessed 27 May 2013] 